\title{
UTJECAJ TOPLINE I MEHANIČKE SKARIFIKACIJE NA SKRAĆIVANJE DORMANTNOSTI ODABRANIH SORATA JEČMA
}

\author{
THE INFLUENCE OF HEAT AND MECHANICAL SCARIFICATION \\ ON SHORTENING SEED DORMANCY OF \\ CHOSEN BARLEY CULTIVARS
}

\author{
Ana Matković, Ž. Jukić, Snježana Kereša, Klaudija Carović-Stanko
}

\section{SAŽETAK}

Cilj ovog rada bio je utvrditi utjecaj tretmana zagrijanim zrakom i mehaničke skarifikacije na dormantnost sjemena odabranih dormantnih sorata ječma (Bc Vedran i Favorit) proizvedenog u dvije vegetacijske sezone (2015. i 2016. godina). U prvom pokusu sjeme dormantnih sorata tretirano je zagrijanim zrakom temperature $45^{\circ} \mathrm{C}$ tijekom 15 minuta i 30 minuta. Prvo utvrđivanje klijavosti u navedenim tretmanima započelo je 2. tjedna nakon žetve te se kasnije provodilo svakih 7 dana narednih 9 tjedana. U drugom pokusu sjeme dormantnih sorata ječma je tretirano mehaničkom skarifikacijom (uklonjene su pljevice) te je utvrđivana klijavost u 2. tjednu nakon žetve.

Rezultati istraživanja pokazuju kako su obje sorte bile dormantne 9 tjedana u prvoj godini istraživanja (2015.), i 8 tjedana u drugoj godini istraživanja (2016.). Tretman dormantnog sjemena ječma (Bc Vedran i Favorit) zagrijanim zrakom nije utjecao na skraćivanje dormantnosti. Prekidanje dormantnosti postignuto je mehaničkom skarifikacijom u obje godine i kod obje sorte (2015. i 2016.; Bc Vedran 100\%, te 2015. i 2016.; Favorit 99\%). Energija klijanja mehanički skarificiranog sjemena bila je veća nego energija klijanja kontrolnog sjemena u obje godine i kod obje sorte.

Ključne riječi: ječam, skraćivanje dormantnosti, klijavost, tretmani

\section{ABSTRACT}

This research was conducted to determine the impact of heat treatment and mechanical scarification on seed dormancy of dormant barley cultivars $(\mathrm{Bc}$ Vedran i Favorit) grown in two seasons (2015. and 2016.). In the first experiment, the heat treatment of dormant seed was $45^{\circ} \mathrm{C}$ for 15 minutes and for 
Ana Matković i sur.: Utjecaj topline i mehaničke skarifikacije na skraćivanje dormantnosti odabranih sorata ječma

the 30 minutes. The first determination of germination in these treatments started on the $2^{\text {nd }}$ week after harvest and was then carried out every 7 days for the next 9 weeks. In the second experiment, mechanical scarification of dormant barley seed was done by peeling the glumes away and germination was determined in the $2^{\text {nd }}$ week after harvest.

The results of the research showing that both cultivars were dormant for 9 weeks in the first year of the research (2015.), and during the 8 weeks in the second year of the research (2016.). Treatment of dormant barley seed (Bc Vedran and Favorit) with heat did not have any effect on shortening of seed dormancy. Dormancy shortening was achieved with mechanical scarification in both years and both cultivars (2015 and 2016; Bc Vedran 100\%, 2015 and 2016; Favorit 99\%). Germination energy increased after mechanical scarification in both years and both cultivars.

Key words: barley, dormancy shortening, germination, treatments

\section{UVOD}

Dormantnost je pojava kada vijabilno sjeme ne klije iako za klijanje postoje povoljni uvjeti (Bewley, 1997.; Finch-Savage i Leubner-Metzger, 2006. - cit. Bentsink i Koornneef, 2008.), a može se regulirati čimbenicima kao što su temperatura, vlaga, svjetlost, kisik i unutarnjim faktorima kao što su fitohormoni (Baskin i Baskin, 1998. - cit. Hoang i sur., 2013.). Postoje razne kategorije dormantnosti, no većina autora slaže se u osnovnoj podjeli na primarnu i sekundarnu dormantnost (Nasreen i sur., 2002.; Khan, 1980.). Primarna dormantnost sjemena je pojava koja očituje se odmah nakon osipanja sjemena s majčinske biljke, a sjeme ne klije u povoljnim okolinskim uvjetima (Koornneef i Karssen, 1994. - cit. Debeaujon i sur., 2000.). Ovisi o genotipu (Alboresi i sur., 2005.) te okolišnim i klimatskim uvjetima koji su vladali tijekom vegetacije u vremenu rasta i razvoja majčinske biljke (Sawhney i Naylor, 1982.; Richardson, 1979.). Za razliku od primarne dormantnosti, sekundarna dormantnost može se javiti kod sjemena koje nije bilo dormantno ili kod sjemena koje je već prethodno imalo cjelovitu ili djelomičnu primarnu dormantnost (Karssen 1980.; Kebreab i Murdoch, 1999.; Hilhorst, 2007.). Takva dormantnost nastaje u zrelom sjemenu nakon upijanja vode kao rezultat nepovoljnih uvjeti za klijanje (Amen, 1968. - cit. Hilhorst, 2007.), a može se prekinuti i ponovno javljati tijekom nekoliko godina (Karssen 1982. - cit. Bouwmeester i Karssen, 1996.). 
Ana Matković i sur.: Utjecaj topline i mehaničke skarifikacije na skraćivanje dormantnosti odabranih sorata ječma

Sekundarna dormantnost sjemena ječma može biti posljedica utjecaja visokih temperatura tijekom klijanja sjemena (Leymarie i sur., 2008.), ili stanja hipoksije koje se može javiti ovisno o temperaturi tijekom naklijavanja (Hoang i sur., 2013.).

Dormantnost najčešće nestaje tijekom suhog skladištenja sjemena, a ta se pojava naziva posliježetveno dozrijevanje (Briggs i sur., 1994.; Donohue i sur., 2005. - cit. Holdsworth i sur., 2008.; (Bewley i Black, 1982. - Derkx i Karseen, 1993.). Stoga će, uz utjecaj okoline i klime tijekom razvoja sjemena, uvjeti koji vladaju tijekom skladištenja posebno temperatura ali i relativna vlaga u skladištu, odrediti duljinu trajanja posliježetvenog dozrijevanja i dormantnosti (Basbouss-Serhal i sur., 2016.; Donohue i sur., 2005. - cit. Holdsworth i sur., 2008.). Dormantnost se može skratiti ili prekinuti, a klijavost povećati slijedećim postupcima: naklijavanjem u mraku (Gubler i sur., 2008.), tretiranjem sjemena svjetlom različitog spektra (Burger, 1965.; Pons, 1991.; Baskin i Baskin, 1998.), tretiranjem sjemena kemikalijama i hormonima (vodikov peroksid, natrijev i kalijev hidroksid, $\mathrm{GA}_{3}$ ) (Ogawa i Iwabuchi, 2001.; Hou i Simpson, 1994.; Vieira i sur., 2002.), tretiranjem sjemena visokim i niskim temperaturama (Reuss i sur., 2004.; Bethke i sur., 2004.; Baskin i Baskin, 1998.), mehaničkom skarifikacijom (Baskin i Baskin, 1998. - cit. Baskin i Baskin, 2004.; Lenoir i sur., 1986.) te suhim skladištenjem sjemena (Baskin i Baskin, 1998.; Lenoir i sur. 1986.). Sjeme nekih kultura može se mehanički skarificirati uz pomoć brusnog papira velike granulacije ili pomoću mehaničkog ručnog mlinca u kojem se nalazi rotirajuća abrazivna žičana četka tako da se stružu vanjski slojevi sjemenog omotača (González-Melero i sur., 1997.; Uzun i Aydin, 2004.; Palmer i sur., 1970.). Jedan od načina prekidanja dormantnosti je tretiranje sjemena zagrijanim zrakom temperature $50{ }^{\circ} \mathrm{C}$ ili više kroz određeno vrijeme (Reuss i sur., 2004.; Shiratsuchi i sur., 2017.).

U ovom radu istraživana je duljina trajanja dormantnosti sorata te utjecaj tretmana zagrijanim zrakom i mehaničke skarifikacije sjemena na skraćivanje dormantnosti odabranih sorata ječma.

\section{MATERIJALI I METODE}

Istraživanje je provedeno na uzorcima ječma proizvedenim 2015. i 2016. godine na poljima $\mathrm{Bc}$ Instituta u Botincu, a utvrđivanje klijavosti obavljeno je u laboratoriju Zavoda za specijalnu proizvodnju bilja Agronomskog fakulteta Sveučilišta u Zagrebu. U dvogodišnjem istraživanju bilo je pet ozimih sorata dvorednog ječma: Bc Bosut, Bc Vedran, Barun, Vanessa i Mombasa, te dvije 
Ana Matković i sur.: Utjecaj topline i mehaničke skarifikacije na skraćivanje dormantnosti odabranih sorata ječma

ozime sorte višerednog ječma: Favorit i Lord. Tijekom trajanja pokusa u prostoru u kojem se obavljalo naklijavanje sjemena vršena su mjerenja temperature i relativne vlažnosti zraka.

Prije tretmana zagrijanim zrakom te prije tretmana mehaničke skarifikacije, izvršeno je naklijavanje sjemena neposredno nakon žetve. U Petrijeve zdjelice promjera $14 \mathrm{~cm}$ sjeme obje sorte stavljeno je na 2 filter papira, a pomoću pipete je dodano $6 \mathrm{ml}$ vode te su Petrijeve zdjelice zatim zatvorene parafilmom. Klijavost je određivana brojenjem klijavih sjemenki od ukupnog broja sjemenki sedmog dana od početka naklijavanja. Energija klijanja određena je brojenjem klijavih sjemenki od ukupnog broja sjemenki tijekom četiri dana od početka naklijavanja. Cilj ovog naklijavanja bio je odrediti klijavost sjemena svake sorte i odabrati dormantne sorte ječma. Utvrđene su dvije dormantne sorte ječma, Bc Vedran i Favorit.

Prvi pokus u kojem se sjeme tretiralo zagrijanim zrakom napravljen je u 2015. godini, dok je u 2015. godini i 2016. godini napravljen drugi pokus tretmanom mehaničke skarifikacije. Međutim, u 2016. godini utvrđeno je trajanje dormantnosti sjemena bez tretmana zagrijanim zrakom. U 2016. godini prosječna dnevna temperatura zraka tijekom 8 tjedana skladištenja uzoraka iznosila je $25,1{ }^{\circ} \mathrm{C}$, dok je u istoj godini prosječna relativna vlaga zraka iznosila $65 \%$.

$\mathrm{U}$ prvom pokusu $\mathrm{s}$ temperaturnim tretmanima, sjeme dormantnih sorata tretirano je u sušnici zagrijanim zrakom temperature $45{ }^{\circ} \mathrm{C}$ tijekom 15 i 30 minuta na početku pokusa. Utvrđivanje klijavosti u navedenim tretmanima započelo je 2. tjedna nakon žetve te se kasnije provodilo svakih 7 dana narednih 9 tjedana. Nakon što je sjeme sorata Bc Vedran i Favorit tretirano zagrijanim zrakom, sjeme obje sorte stavljeno je u Petrijevu zdjelicu u 2 ponavljanja (100 sjemenki po jednoj Petrijevoj zdjelici). Utvrđivanje klijavosti u navedenim tretmanima započelo je 2 . tjedna nakon žetve te se kasnije provodilo svakih 7 dana narednih 9 tjedana. Prosječna dnevna temperatura zraka tijekom 9 tjedana skladištenja uzoraka iznosila je $24,8{ }^{\circ} \mathrm{C}$, dok je prosječna relativna vlaga zraka iznosila $61 \%$ u 2015 . godini.

U drugom pokusu, sjeme dormantnih sorata ječma (Bc Vedran i Favorit) dva tjedna nakon žetve stavljeno je u posudicu s vodom na 10 minuta kako bi pljevice omekšale. Temperatura vode iznosila je $18{ }^{\circ} \mathrm{C}$. Za mehaničku skarifikaciju sjemena korišten je alat (pinceta) kojim su pljevice oguljene i uklonjene sa sjemena. Nakon što je sjeme sorata Bc Vedran i Favorit mehanički skarificirano, sjeme obje sorte stavljeno je u Petrijeve zdjelice u 2 ponavljanja (100 sjemenki po jednoj Petrijevoj zdjelici). Tretirano i kontrolno sjeme 2 tjedna od žetve stavljeno je na klijanje. 
Ana Matković i sur.: Utjecaj topline i mehaničke skarifikacije na skraćivanje dormantnosti odabranih sorata ječma

U ovom istraživanju korišten je statistički računalni program SPSS ${ }^{\circledR}$ i SAS za obradu podataka. Dobiveni podatci su statistički obrađeni analizom varijance (ANOVA), a srednje vrijednosti uspoređene su Duncan-ovim testom na razini signifikantnosti $\mathrm{P} \leq 0,05$.

\section{REZULTATI I RASPRAVA}

Ispitivanjem klijavosti tjedan dana nakon žetve u 2015. godini i u 2016. godini utvrđeno je kako su, od ukupno sedam sorata koliko ih je bilo u istraživanju, dvije sorte bile dormantne (Grafikon 1). To su bile sorte Bc Vedran i Favorit. U obje su godine dormantne sorte imale nižu klijavost u usporedbi s ostalim sortama čija je klijavost iznosila više od $95 \%$. Klijavost sjemena dormantnih sorata bila je neznatno veća u 2015. godini nego u 2016. godini. S obzirom da je cilj istraživanja bio utvrditi duljinu trajanja dormantnosti sorata te utjecaj tretmana zagrijanim zrakom i mehaničke skarifikacije sjemena na skraćivanje dormantnosti odabranih sorata ječma, daljnja istraživanja obavljena su na dvije prije navedene sorte.

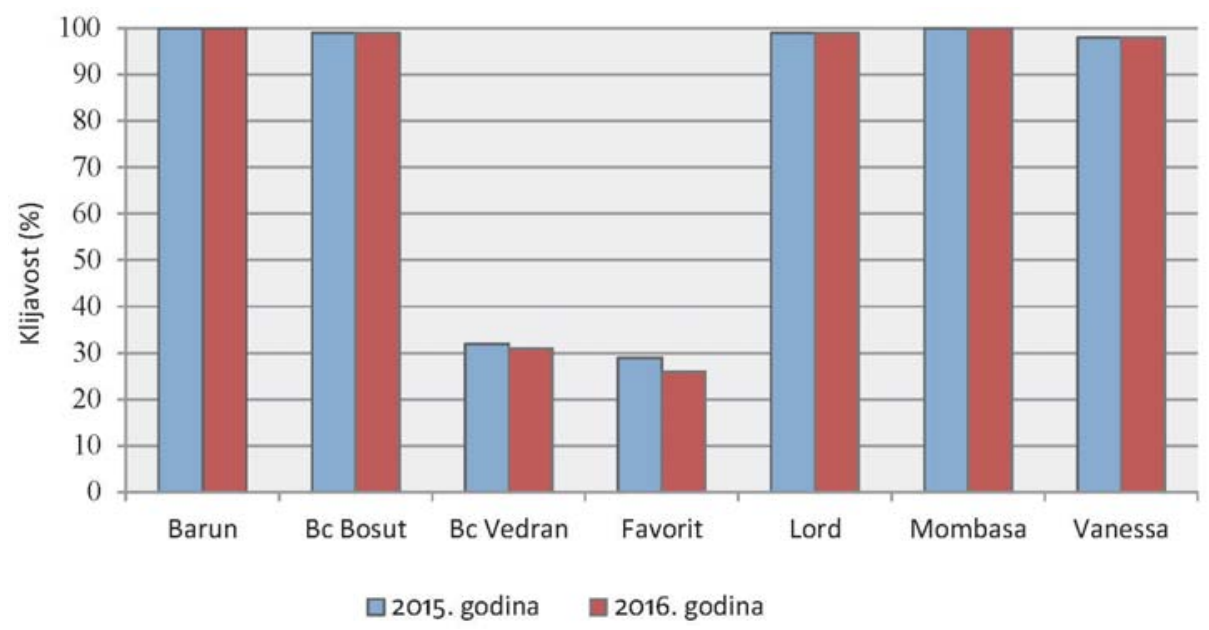

Grafikon 1.: Broj klijavih sjemenki ječma tjedan dana nakon žetve

tijekom 2015. i 2016. godine

Graph 1: Number of germinated barley seeds 1 week after harvest during 2015 and 2016 
Ana Matković i sur.: Utjecaj topline i mehaničke skarifikacije na skraćivanje dormantnosti odabranih sorata ječma

Utvrđeno je kako nema statistički signifikantnih razlika u ukupnoj klijavosti između varijanata u kojima je sjeme tretirano zagrijanim zrakom i kontrolnih varijanti $(\mathrm{p} \leq 0,05)$. Međutim, vidljivo je smanjivanje dormantnosti sjemena ječma neovisno o sorti i tretmanu kako prolaze tjedni od datuma žetve (Grafikoni 2 i 3). Potpuno prekidanje dormantnosti za obje sorte utvrđeno je 9. tjedan nakon žetve u 2015. godini, te 8 . tjedan nakon žetve u 2016. godini (podaci nisu prikazani). Dobiveni rezultati sukladni su s istraživanjem Reuss i sur. (2004.) koji su zaključili kako je tretiranje sjemena ječma zagrijanim zrakom temperature ispod $50{ }^{\circ} \mathrm{C}$ tijekom $1 \mathrm{~h}$, imalo vrlo malog utjecaja na smanjenje dormantnosti. Isti autori su također tretirali sjeme ječma sa zagrijanim zrakom temperature $60{ }^{\circ} \mathrm{C}$ tijekom $5 \mathrm{~h}$, ali su tada utvrdili kako je takav tretman smanjio dormantnost sorata. Zaključili su kako je tretiranje sjemena zagrijanim zrakom temperature $70^{\circ} \mathrm{C}$ imalo pozitivan utjecaj na smanjenje dormantnosti sjemena, ali samo ako tretman nije trajao duže od 30 min.

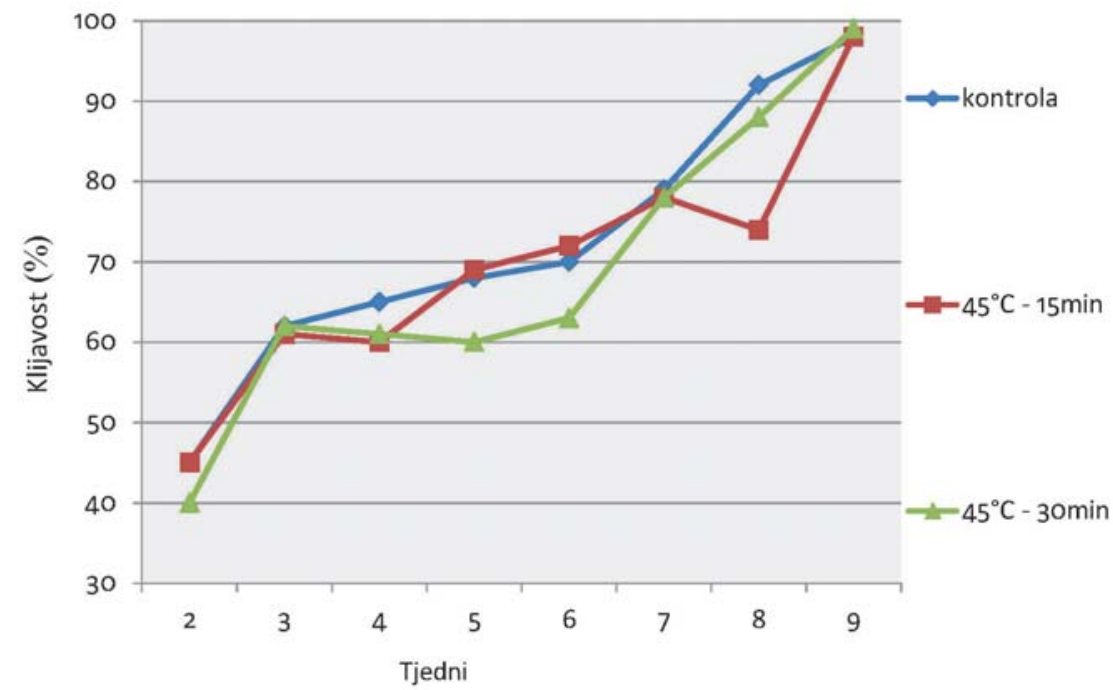

Grafikon 2: Utjecaj različitih temperaturnih tretmana na klijavost sjemena sorte Bc Vedran od 2. do 9. tjedna nakon žetve

Graph 2: Influence of different temperature treatments on seed germination of cultivar $B c$ Vedran from $2^{\text {nd }}$ to $9^{\text {th }}$ week after harvest 
Ana Matković i sur.: Utjecaj topline i mehaničke skarifikacije na skraćivanje dormantnosti odabranih sorata ječma

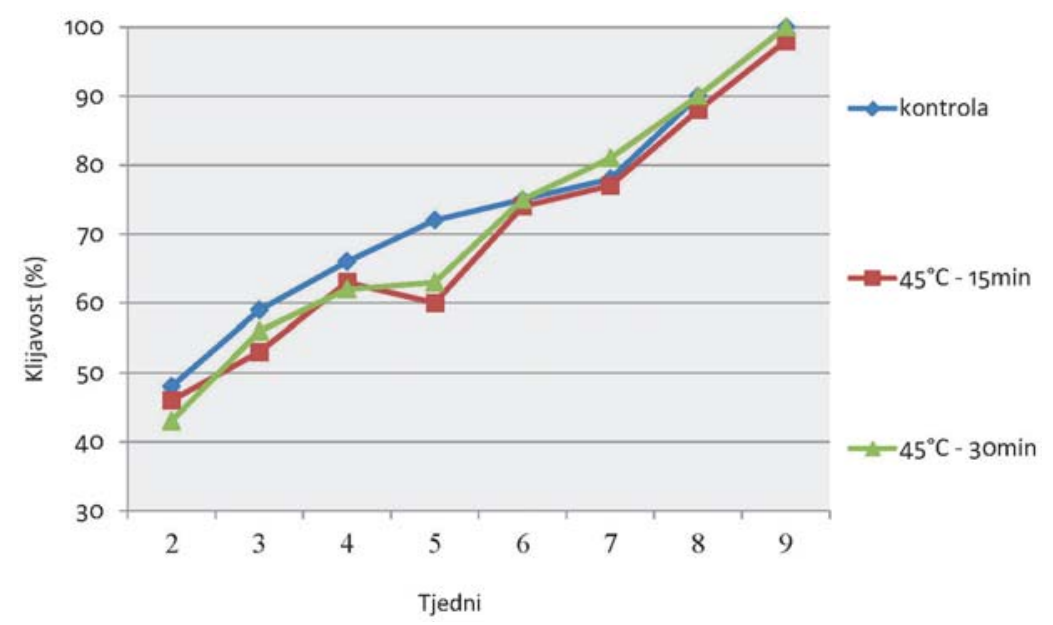

Grafikon 3: Utjecaj različitih temperaturnih tretmana na klijavost sjemena sorte Favorit od 2. do 9. tjedna nakon žetve

Graph 3: Influence of different temperature treatments on seed germination of Favorit seed from $2^{\text {nd }}$ to $9^{\text {th }}$ week after harvest

Tretman mehaničke skarifikacije sjemena značajno je povećao klijavost sjemena koje je bilo dormantno odmah nakon žetve (grafikon 4). Sjeme kontrolne varijante sorata Bc Vedran i Favorit u obje godine istraživanja (2015. i 2016. godina) ostvarilo je nižu ukupnu klijavost od mehanički skarificiranog sjemena. Sjeme kontrolne varijante obiju sorata u prvoj godini istraživanja (2015. godini), imalo je veću ukupnu klijavost (Bc Vedran: 44\% i Favorit: 35\%) od klijavosti sjemena u drugoj godini istraživanja (2016. godina; Bc Vedran: 35\% i Favorit: 33\%).

Rezultati su u skladu s istraživanjem Benech-Arnold i sur. (2006.) koji su također utvrdili kako je mehanička skarifikacija sjemena ječma pospješila klijanje sjemena ječma (skoro 100\%) u odnosu na kontrolno sjeme koje gotovo i nije klijalo. Brown (1974.) je utvrdio kako se tretman abrazije sjemena brusnim papirom pokazao uspješnim u povećanju klijavosti dormantnog sjemena ječma. Pollock i sur. (1955.) dormantno sjeme ječma su u prvom pokusu stavili u mlin kojem se nalazio abrazivni materijal (porculanske kuglice) pomoću kojeg se mehanički tretiralo sjeme, dok su u drugom pokusu skarificirali vanjski omotač sjemena i embrijo pomoću oštre igle. Zaključili su kako u oba pokusa dolazi do značajnog povećanja klijavosti $(100 \%) \mathrm{u}$ odnosu na kontrolu (13\%). Bishop (1944.) je pomoću prethodno navedenog mlina sa abrazivnim materijalom također tretirao dormantno sjeme ječma te je utvrdio kako je mehanički skarificirano sjeme bolje klijalo (100\%) u odnosu na kontrolu (18\%). 
Ana Matković i sur.: Utjecaj topline i mehaničke skarifikacije na skraćivanje dormantnosti odabranih sorata ječma

Lenoir i sur. (1986.) utvrdili su kako je odmah nakon žetve, klijanje sjemena ječma kojemu su uklonjene pljevice (obuvenac sjemena) pri temperaturi od $25{ }^{\circ} \mathrm{C}$ bilo bolje od klijanja kontrolnog sjemena. Rezultati tog istraživanja su u suglasju s rezultatima ovog rada gdje je također dokazano kako je mehanički skarificirano sjeme ječma obje sorte u obje godine klijalo bolje nego kontrolno sjeme. Iz rezultata ovog istraživanja, ne može se utvrditi uslijed čega je nastala razlika u klijavosti kontrolnog i tretiranog sjemena kod sorata Bc Vedran i Favorit. Literaturni navodi ukazuju da je navedena razlika u klijavosti možda nastala zato što su omotač ploda i sjemena ili pljevice sprječavale dotok dovoljne količine kisika do klice (embrija) (Corbineau i Come 1980. - cit. Lenoir et al. 1986.; Rosa i Corbineau, 1986.; Lenoir et al. 1986.).

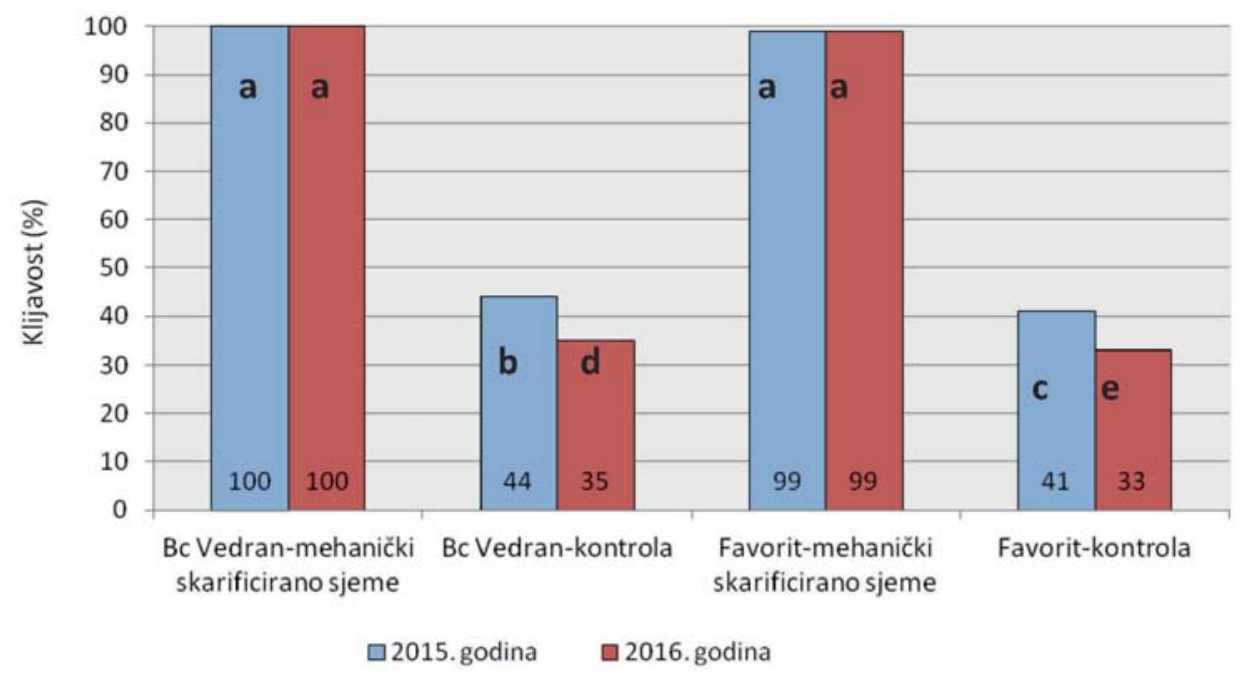

Grafikon 4. Ukupna klijavost mehanički skarificiranog i kontrolnog sjemena sorte Bc Vedran i Favorit iz 2015. i 2016. godine

Figure 4: Total germination of mechanically scarified seed and control of cultivars Bc Vedran and Favorit in 2015. and 2016.

Energija klijanja sjemena kontrolnog i mehanički skarificiranog sjemena sorata Bc Vedran i Favorit drugi tjedan nakon žetve u 2015. godini i 2016. godini prikazana je na grafikonima 5. i 6. Rezultati istraživanja pokazuju kako je mehanički skarificirano sjeme sorata $\mathrm{Bc}$ Vedran i Favorit, u obje godine istraživanja, imalo bolju energiju klijanja od kontrolnog sjemena. Tijekom obje godine istraživanja i kod obje sorte, mehanički skarificirano sjeme započelo je klijati tijekom 2. dana, dok je kontrolno sjeme klijalo tek tijekom 3. dana. 
Ana Matković i sur.: Utjecaj topline i mehaničke skarifikacije na skraćivanje dormantnosti odabranih sorata ječma

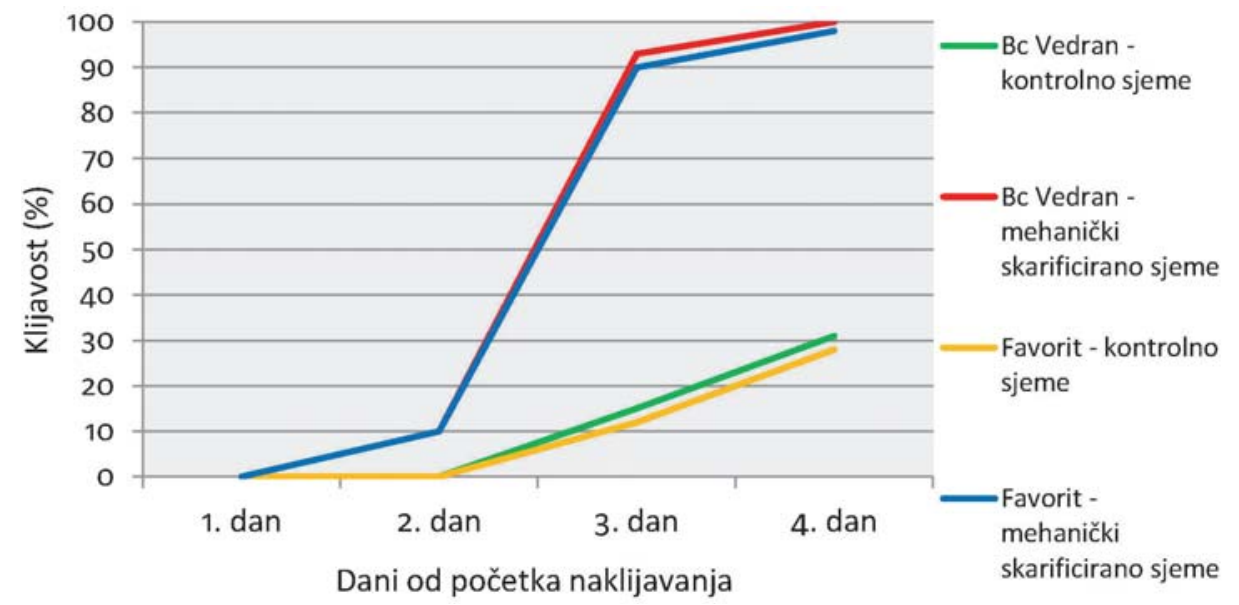

Grafikon 5: Energija klijanja sjemena sorte Favorit:

kontrola i nakon tretmana zagrijanim zrakom 15 min i $30 \mathrm{~min} ;$ 2. $i$ 9.tjedana od žetve

Graph 5: Seed germination energy of cultivar Favorit:

control and after heat treatments $15 \mathrm{~min}$ and $30 \mathrm{~min} ; 2$. and 9. weeks after harvest

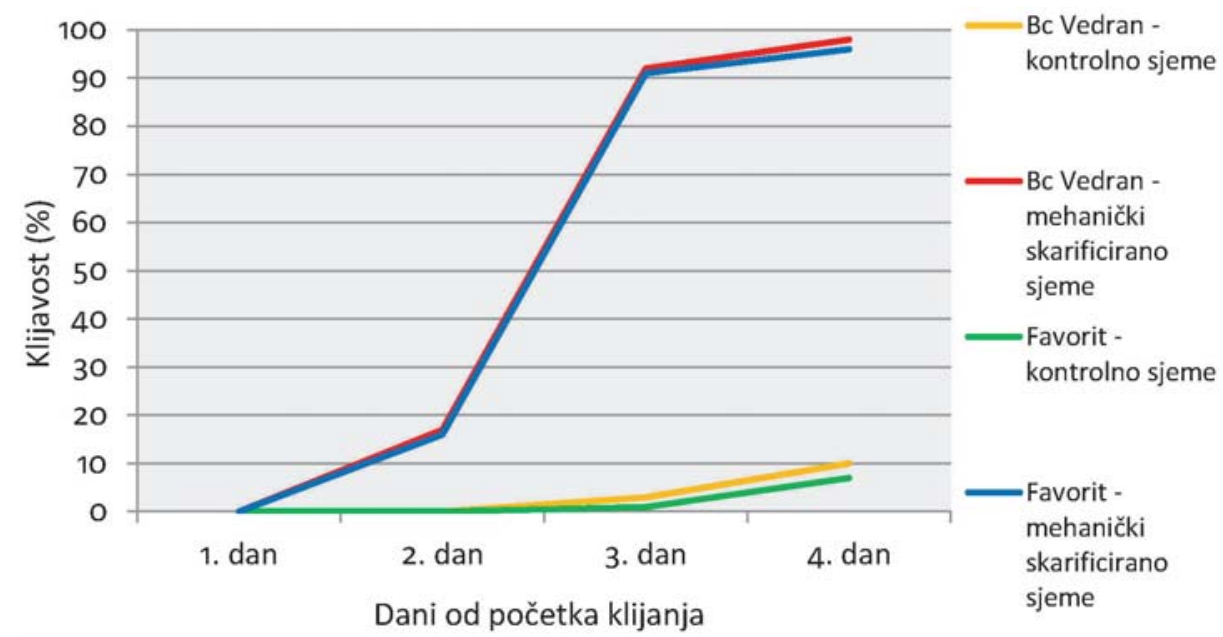

Grafikon 6.Ukupna klijavost mehanički skarificiranog sjemena i kontrolnog sjemena sorte Bc Vedran i Favorit u 2015. i 2016., 2 tjedna od žetve

Graph 6: Total germination of mechanically scarified seed and control of cultivar Bc Vedran and Favorit in 2015. and 2016., 2 weeks after harvest 
Ana Matković i sur.: Utjecaj topline i mehaničke skarifikacije na skraćivanje dormantnosti odabranih sorata ječma

Na slici 1. prikazano je sjeme ječma sorata Bc Vedran i Favorit (kontrolno sjeme i mehanički skarificirano sjeme) sedmog dan naklijavanja nakon postavljanja pokusa 2 tjedna nakon žetve u 2016. godini. Energija klijanja sjemena ječma povećava se u odnosu na broj dana koji je prošao od naklijavanja. Vidljivo je kako je mehanički skarificirano sjeme, kod obje sorte, brže i bolje klijalo od kontrolnog sjemena.

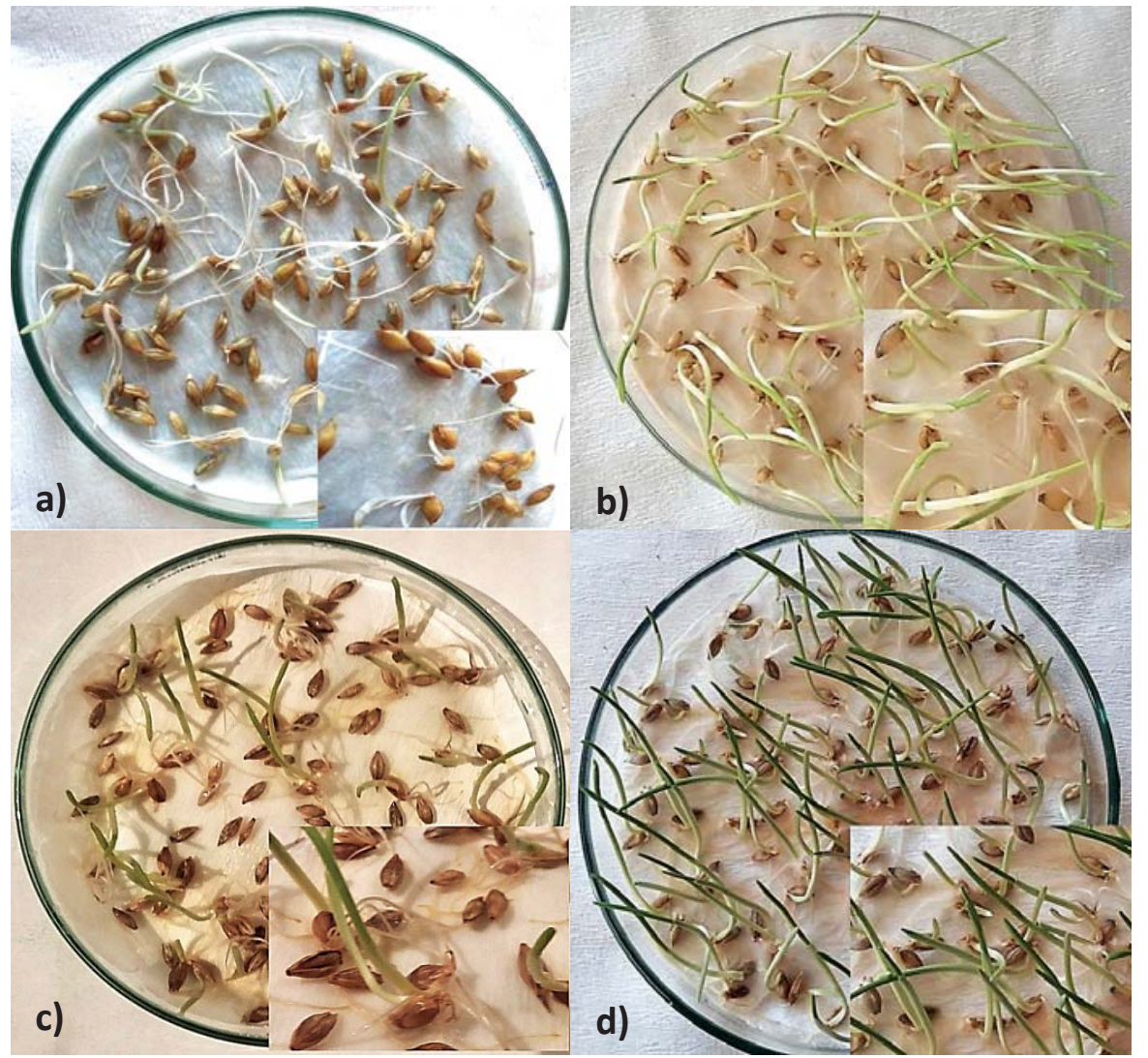

Slika 1: Sorte Bc Vedran i Favorit 7 dana nakon naklijavanja (a-kontrolno sjeme sorte $B c$ Vedran, $b$-mehanički skarificirano sjeme sorte Bc Vedran, $c$-kontrolno sjeme sorte Favorit, $d$-mehanički skarificirano sjeme sorte Favorit)

Fotografirala: Ana Matković

Picture 1: Cultivars Bc Vedran and Favorit 7 days after germination (a-control seed of cultivar Bc Vedran, $b$-mechanically scarified seed of cultivar Bc Vedran, $c-$ control seed of cultivar Favorit, $d$ - mechanically scarified seed of cultivar Favorit) Photo by: Ana Matković 
Ana Matković i sur.: Utjecaj topline i mehaničke skarifikacije na skraćivanje dormantnosti odabranih sorata ječma

\section{ZAKLJUČAK}

Istraživanjem je utvrđeno kako su dvije dormantne sorte ječma (Bc Vedran i Favorit) bile dormantne. Istraživanja su pokazala kako tretiranjem sjemena zagrijanim zrakom $\left(45^{\circ} \mathrm{C}\right)$ nije skraćena dormantnost sjemena ječma kod sorte Bc Vedran i Favorit u usporedbi s kontrolnom varijantom, neovisno o duljini trajanja tretmana (15 min i $30 \mathrm{~min}$ ). Dormantnost kontrolnog sjemena je u prvoj godini trajala 9 tjedana, dok je u drugoj godini trajala 8 tjedana. To je dokaz da se posliježetvenim dozrijevanjem dormantnost sjemena ječma sorata Bc Vedran i Favorit nakon nekog vremena prekida neovisno o tretmanu. Mehanička skarifikacija uklanjanja pljevica povećala je klijavost i energiju klijanja sjemena kod obje dormantne sorte ječma. Mehanička skarifikacija je u potpunosti prekinula dormantnost sjemena kod obje sorte i u obje godine (2015. i 2016. godina; Bc Vedran 100\%, te 2015. i 2016. godina; Favorit 99\%).

\section{ZAHVALA}

Zahvaljujem se djelatnicima tvrtke Bc Institut na suradnji tijekom izrade ovog rada.

\section{LITERATURA}

1. Alboresi A., Gestin C., Leydecker M. -T., Bedu M., Meyer C. , Truong H.-N. (2005.): Nitrate, a signal relieving seed dormancy in Arabidopsis. Plant, Cell and Environment. 28(4): 500-512. DOI: 10.1111/j.1365-3040.2005.01292.x

2. Amen R. D. (1968): A model of seed dormancy. Botanical Review. 34: 1-31

3. Basbouss-Serhal I., Leymarie J., Bailly C. (2016.): Fluctuation of Arabidopsis seed dormancy with relative humidity and temperature during dry storage. Journal of Experimental Botany. 67(1): 119-130. DOI: 10.1093/jxb/erv439

4. Baskin J.M., Baskin C.C. (1998.): Seeds: ecology, biogeography and evolution of dormancy and germination. San Diego: Academic Press.

5. Baskin J.M., Baskin C.C. (2004.): A classification system for seed dormancy. Seed Science Research: 14(01): 1-16. DOI: 10.1079/SSR2003150

6. Benech-Arnold R.L., Gualano N., Leymarie J., Côme D., Corbineau F. (2006.): Hypoxia interferes with $\mathrm{ABA}$ metabolism and increases $\mathrm{ABA}$ sensitivity in embryos of dormant barley grains. Journal of Experimental Botany. 57(6): 1423-1430. DOI: $10.1093 / \mathrm{jxb} / \mathrm{erj} 122$

7. Bentsink L., Koornneef M. (2008.): Seed dormancy and germination. The Arabidopsis Book. 6: e0119. DOI: 10.1199/tab.0119 
Ana Matković i sur.: Utjecaj topline i mehaničke skarifikacije na skraćivanje dormantnosti odabranih sorata ječma

8. Bethke P.C., Gubler F., Jacobsen J.V., Jones R.L. (2004.): Dormancy of Arabidopsis seeds and barley grains can be broken by nitric oxide. Planta 219(5): 847-855. DOI: 10.1007/s00425-004-1282-x

9. Bewley J.D. (1997.): Seed germination and dormancy. The Plant Cell. 9: 10551066. DOI: $10.1105 /$ tpc.9.7.1055

10. Bewley J.D., Black M. (1982.): Physiology and biochemistry of seeds in relation to germination. Volume 2: Viability, dormancy, and environmental control. Springer-Verlag Berlin Heidelberg.

11. Bishop L.R. (1944.): Memorandum on barley germination. Journal of the Institute of Brewing. 50(4): 166-185.

12. Bouwmeester H.J., Karssen C.M. (1996.): The seed bank in the soil, that great unknown in rare plant population studies. Bocconea 5: 159-170.

13. Briggs D.E., Woods J.L., Favier J.F. (1994.): Drying and storage treatments for overcoming dormancy in malting barley. Journal of the Institute of Brewing. 100: 271-278.

14. Brown C.R. (1974.): The effect of abrasion on dormant barley. Journal of the Institute of Brewing. 80(5): 471-473. DOI: 10.1002/j.2050-416.1974.tb06796.x

15. Burger W. C. (1965.): Effect of light on the germination of barley and its relation to dormancy. Journal of The Institute of Brewing. 71(3): 244-250. DOI: 10.1002/j.2050-0416.1965.tb02053.x

16. Corbineau F., Come D. (1980.): Quelques caracteristiques de la dormance du caryopse d'Orge (Hordeum vulgare L., variete Sonja). Comptes Rendus Hebdomadaires des Seances de l'Academie des Sciences, 290(7): 547-550.

17. Debeaujon I., Léon-Kloosterziel K.M., Koornneef M. (2000.): Influence of the testa on seed dormancy, germination, and longevity in Arabidopsis. Plant Physiology. 122(2): 403-414.

18. Derkx M.P.M, Karssen C.M. (1993): Variability in light-, gibberellin-, and nitrate requirement of Arabidopsis thaliana seeds due to harvest time and conditions of dry storage. Journal of Plant Physiology. 141(5): 574-582. DOI: 10.1016/S0176-1617(11)80459-1

19. Donohue K., Dorn L., Griffith C., Kim E., Aguilera A., Polisetty C.R., Schmitt J. (2005.): The evolutionary ecology of seed germination of Arabidopsis thaliana: variable natural selection on germination timing. Evolution. 59(4): 758-770.

20. Finch-Savage W.E., Leubner-Metzger G. (2006.): Seed dormancy and the control of germination. New Phytol. 171(3): 501-523. DOI: 10.1111/j.14698137.2006.01787.x 
Ana Matković i sur.: Utjecaj topline i mehaničke skarifikacije na skraćivanje dormantnosti odabranih sorata ječma

21. González-Melero J.A., Pérez-Garcia F., Martínez-Laborde J.B. (1997.): Effect of temperature, scarification and gibberellic acid on the seed germination of three shrubby species of Coronilla L. (Leguminosae). Seed Sci \& Technol. 25: 167-175.

22. Gubler F., Hughes T., Waterhouse P., Jacobsen J. (2008.): Regulation of dormancy in barley by blue light and after-ripening: effects on abscisic acid and gibberellin metabolism. Plant physiology. 147: 886-896. DOI: 10.1104/pp.107.115469

23. Hilhorst, H.W.M. (2007.): Definitions and hypotheses of seed dormancy. 5071. In: Bradford, K.; Nonogaki, H. (2008): Seed development, dormancy and germination. Annual Plant Reviews. 27: 877-878. DOI: 10.1002/9780470988848.ch3

24. Hoang H.H., Bailly C., Corbineau F., Leymarie J. (2013.): Induction of secondary dormancy by hypoxia in barley grains and its hormonal regulation. Journal of Experimental Botany. 64(7): 2017-2025. DOI: 10.1093/jxb/ert062

25. Holdsworth M.J., Bentsink L., Soppe W.J.J. (2008.): Molecular networks regulating Arabidopsis seed maturation, after-ripening, dormancy and germination. New Phytologist. 179(1): 33-54. DOI: 10.1111/j.14698137.2008.02437.x

26. Hou J.Q., Simpson G.M. (1994.): Promoting germination of freshly harvested barley grain with alkaline solutions. Journal of the Institute of Brewing. 100(6): 421-425. DOI: 10.1002/j.2050-0416.1994.tb00841.x

27. Karssen C.M. (1980.): Environmental conditions and endogenous mechanisms involved in secondary dormancy of seeds. Israel Journal of Botany. 29:1-4, 45-64.

28. Karssen C.M. (1982.): Seasonal patterns of dormancy in weed seeds. - pp. 243 270 In: Khan, A.A. (ed.), The physiology and biochemistry of seed development, dormancy and germination. Amsterdam.

29. Kebreab E., Murdoch A.J. (1999.): A quantitative model for loss of primary dormancy and induction of secondary dormancy in imbibed seeds of Orobanche spp. Journal of Experimental Botany. 50(331): 211-219.

30. Khan A.A. (1980.): Hormonal regulation of primary and secondary seed dormancy. Israel Journal of Botany. 29(1-4): 207-224.

31. Koornneef M., Karssen C.M. (1994.): Seed dormancy and germination. In: Meyerowitz EM, Somerville CR, editors. Arabidopsis. Cold Spring Harbor, NY: Cold Spring Harbor Laboratory Press; 1994. 313-334. 
Ana Matković i sur.: Utjecaj topline i mehaničke skarifikacije na skraćivanje dormantnosti odabranih sorata ječma

32. Lenoir C., Corbineau F., Côme D. (1986.): Barley (Hordeum vulgare) seed dormancy as related to glumella characteristics. Physiologia Plantarum. 68(2): 301-307. DOI: 10.1111/j.1399-3054.1986.tb01930.x

33. Leymarie J., Robayo-Romero M.E., Gendreau E., Benech-Arnold R.L., Corbineau F. (2008.): Involvement of ABA in induction of secondary dormancy in barley (Hordeum vulgare L.) seeds. Plant Cell Physiol. 49(12): 1830-1838. DOI: $10.1093 / \mathrm{pcp} / \mathrm{pcn} 164$

34. Nasreen S., Yousaf M., Mohmand A.S., Ashraf Mailk M. (2002.): Study of seed dormancy mechanisms; causes and control. Asian Journal of Plant Sciences. 1: 210-212.

35. Ogawa K., Iwabuchi M. (2001.): A mechanism for promoting the germination of Zinnia Elegans seeds by hydrogen peroxide. Plant Cell Physiol. 42(3): 286291. DOI: $10.1093 / \mathrm{pcp} / \mathrm{pce} 032$

36. Palmer G.H., Barrett J., Kirshop B.H. (1970.): Malting and brewing properties of abraded barley. Journal of The Institute of Brewing. 76(1): 65-68. DOI: $10.1002 / \mathrm{j} .2050-0416.1970 . t b 03263 . \mathrm{x}$

37. Pollock J.R.A., Kirsop B.H., Essery R.E. (1955.): Studies in barley and malt: IV. Experiments with dormant barley. Journal of The Institute of Brewing. 61(4): 301-307. DOI: 10.1002/j.2050-0416.1955.tb02799.x

38. Pons T.L. (1991.): Induction of dark dormancy in seeds: its importance for the seed bank in the soil. Functional Ecology. 5: 669-675.

39. Reuss R., Cassells J.A., Green J.R., Wills T., Nischwitz R. (2004.): Effect of chemical and physical processes on malting barley dormancy: The influence of physical and chemical processes on dormancy breakdown in malting barley. Canberra : CSIRO Entomology. Available at: $<$ https://www.researchgate.net/publication/228844673_The_influence_of_phys ical_and_chemical_processes_on_dormancy_breakdown_in_malting_barley>

40. Richardson S.G. (1979.): Factors influencing the development of primary dormancy in wild oat seeds. Canadian Journal of Plant Science. 59: 777-784. DOI: $10.4141 /$ cjps79-120

41. Rosa M.L., Corbineau F. (1986): Quelques aspects de la germination des caryopses de Leersia oryzoides (L.) Sw. Weed research. 26(2): 99-104. DOI: 10.1111/j.1365-3180.1986.tb00682.x

42. Sawhney R., Naylor J.M. (1982.): Dormancy studies in seed of Avena fatua. 13. Influence of drought stress during seed development on duration of seed dormancy. Canadian Journal of Botany. 60: 1016-1020. DOI: 10.1139/b82-127 
Ana Matković i sur.: Utjecaj topline i mehaničke skarifikacije na skraćivanje dormantnosti odabranih sorata ječma

43. Shiratsuchi H., Ohdaira Y., Yamaguchi H., Fukuda A. (2017.): Breaking the dormancy of rice seeds with various dormancy levels using steam and high temperature treatments in a steam nursery cabinet. Plant Production Science, 20(2): 183-192. DOI: 10.1080/1343943X.2017.1289067

44. Uzun F., Aydin I. (2004.): Improving germination rate of Medicago and Trifolium species. Asian Journal of Plant Sciences. 3(6): 714-717.

45. Vieira A.R., Vieira M.G.G.C., Fraga A.C., Oliveira J.A., Santos C.D. (2002.): Action of gibberellic acid $\left(\mathrm{GA}_{3}\right)$ on dormancy and activity of a-amylase in rice seeds. Revista Brasileira de Sementes. 24(2): 43-48. DOI: 10.1590/S010131222002000100008

Adrese autora - Author's address:

Primljeno-received:

Ana Matković, mag. ing. agr., 15.01.2018.

e-mail: ana.matk.5@gmail.com

Izv.prof.dr.sc. Željko Jukić,

Zavod za specijalnu proizvodnju bilja

Prof.dr.sc. Snježana Kereša,

Zavod za oplemenjivanje bilja, genetiku i biometriku

Doc.dr.sc. Klaudija Carović-Stanko,

Zavod za sjemenarstvo

Sveučilište u Zagrebu, Agronomski fakultet, Svetošimunska cesta 25, 10000 Zagreb 
Ana Matković i sur.: Utjecaj topline i mehaničke skarifikacije na skraćivanje dormantnosti odabranih sorata ječma 